\title{
Dynamics of Manufacturing Sector Development and Youth Unemployment in Africa
}

\author{
AJEIGBE Omowumi Monisola ${ }^{1}$, OLOMOLA Phillip Akanni ${ }^{2}$, ADELEKE Oluwayemisi Khadijat $^{3}$ \\ ${ }^{1,3}$ Department of Economics, Faculty of Social Sciences, Redeemers University, Ede, Nigeria \\ ${ }^{2}$ Department of Economics, Faculty of Social Sciences, Obafemi Awolowo University, Ile-Ife, Nigeria
}

\begin{abstract}
The study examined the effect of manufacturing sector development on youth unemployment in Africa. The study made use of 33 African countries within the time frame of 2000-2018. Data was sourced from the world development indicators by the World Bank. The estimation technique used was the Panel Autoregressive Distributed lag which deals with the stationary series problem of different orders and allows us to study potential long term effects of structural economic policies. The variables used were in natural logarithms and they are Youth Unemployment, Manufacturing Value Added, Foreign Direct Investment, Gross Capital Formation and Domestic Credit to Private Sector. The result revealed a positive long run relationship among MVA, DCP FDI, GCF and YUEMP. In the short run, MVA and DCP showed a positive relationship to youth unemployment while FDI and GCF showed a negative relationship. The study recommended that to curb the menace of youth unemployment ravaging major African Countries, policy focal point should be directed towards the development of manufacturing sector, conducive economic environment to attract foreign direct investment, policies should be put in place to enhance capital formation with domestic credit being made available for new and existing entrepreneurs and industrialist.
\end{abstract}

Keywords: Manufacturing Value Added, Youth Unemployment, Decent work, Panel Autoregressive Distributed Lag, Africa

\section{INTRODUCTION}

cholars and policymakers have advocated that a robust manufacturing sector is a fundamental path to economic growth and development (Diao, Ellis, McMillian \& Rodrik, 2021, Adegboye et al, 2019, Signe, 2018, Oguntoye \& Evans, 2017). In recent time, the sector have attracted attention of policy makers in Africa based on the launch of the African Free Trade Area (AFCFTA) in March 2018 having the motive of a single market for goods and services, unlocking manufacturing potential and facilitating industrialization so as to drive sustainable growth, decent jobs and enhance inclusive growth (Maryla \& Michele, 2020, Abdychev, et al, 2018). Also, the African Union in their briefings proclaim industrialization as the major strategy to promote and achieve inclusive economic transformation based on the African Union flagship Agenda 2063 which states that a prosperous Africa based on inclusive and sustainable development has industrialization through the manufacturing sector as one of the pillars of achieving this agenda (Okurebia, 2014, Haraguchi et al, 2019, Dinh, Clarke \& George, 2012). In Macroeconomic terms, a strong manufacturing sector has been contended to boost a country's external account balance by reducing imports and diversifying exports which in turns leads to increase in resilience to external shocks when compared to reliance on primary commodities (Anyawu, 2013, Anyawu, 2014, Jostein, 2015).

Manufacturing has been identified to be the path to development as it has been the strategic achievement of rich nations over the last several hundred years to create a high quality manufacturing sector in order to develop national wealth and power (Reinert, 2012). In the field of trade, global trade is based on goods, not services as World Trade Organisation (WTO) revealed that $80 \%$ of the world trade among regions is merchandise trade in which services are mostly the act of using manufactured goods. Retail and wholesale which make up about $11 \%$ of the economy are majorly the act of buying and selling manufactured goods (Diao et al, 2021, Mold, 2017). This goes for real estate, which is the act of buying and selling a real or physical asset (a building). Even health is also the act of using medical equipment and drugs. In the aspect of Finance, which involves redirection of surplus resources that the non-financial sector of the economy produces is also indirectly dependent on manufacturing. This makes the health of an economy to be critically dependent on the health of the manufacturing sector. Through its derived demand for labour resources, manufacturing sector helps in the transfer of labour resources from low productive sectors (or disguised employment) in agriculture and informal sectors to more productive economic segment of industrial sector (Rioba, 2014). Manufacturing creates jobs, which implies that reviving the sector can provide tens of millions of new jobs, reduce poverty, and eradicate youth unemployment, providing decent job and enhanced inclusive growth. A report by (Rynn, 2019) shows that each manufacturing job supports almost three other jobs in the economy.

However, despite the manufacturing potential of most countries in Africa, there still remain relatively dearth of factories, which have limit industrial development. This according to Yuan (2018) triggered a missed opportunity for economic and structural transformation, quality employment generation that can eradicate poverty. Between 2011 and now, some African countries have made progress in this sector based on a report from the United Nations Conference on Trade and Development (UNCTAD) and United Nation Industrial Development Organisation (UNIDO) which 
identified some African countries to have achieve substantial reduction in unemployment based on a process of structural transformation through the manufacturing sector (IFAD, 2011, AFDB, 2016, Fox \& Ghandi, 2021).

The asset Africa has today is the youth population which is growing rapidly in recent time and is expected to double to over 830 million by 2050 (Johnson \& Ubong, 2020, Mesfin, 2020, Fox and Thomas, 2016; Evoh, 2012). A report from the African Capacity Building Foundation (2017) states that Africa's youth population is not only growing rapidly but is also getting better educated with estimates of 137 million of 20 to 24 year olds to have acquired secondary education by 2030 while 12 million of the same age a group would have tertiary education (Nzewi \& Ojiagu, 2014) . It has been revealed by the African Development Bank (2017) that most of the Youth in Africa do not have stable economic opportunities and are faced with double the unemployment rate of adult. The problem with youth in Africa is not only unemployment but underemployment and statistics from AFDB group shows that 10 to 12 million youth enter the workforce each year with only 3.1 million jobs created and this leaves vast numbers of youth unemployed (Parsitau, 2021, Mueller \& Thurlow, 2019, Abdychev et al, 2018) . This indicates that youth unemployment in Africa is pervasive and severe resulting in poorer living conditions, migrations out of Africa, conflict, terrorism, security challenge on Africa (Patel et al, 2020, van Niekerk, 2020). This invariably has made the continent greatest asset for growth which is the large and growing population of talented young people a failure. More so, a large percentage of youth that are employed are mostly engaged in the informal sector which majorly is due to lack of wage jobs (Flynn \& Yeboah, 2021, Fox \& Gandhi, 2020, Rafaeli \& Hutchinson, 2020).

Furthermore, it has been revealed that $90 \%$ of Africa's youth live in low and lower middle income countries and the biggest challenge the youth encounter is the lack of formal jobs (Flynn \& Yeboah, 2021, Fox and Thomas, 2016). Also, these countries youth labour force participation are about $10 \%$ to $15 \%$ who finds wage employment with $30 \%-50 \%$ vulnerably employed (Ayele, Khan \& Sumberg, 2017). A report by John Page (2019) revealed that Africa's working age population will grow by approximately 450 million people which is about 3\% per annum between 2015 and 2035 (Parsitau, 2021, Abdychev, et al, 2018). By 2050, Africa will have 362 million young people between the ages of 15 and 24 years old. Also in Africa, three quarters of her new entrants to the labour market will work in self-employment or in micro-enterprises. More so, $20 \%$ will work for wages in the services sector and only about $4 \%$ to $5 \%$ will find a wage paying job in the industry. However, if these trends continue, only about 100 million of the 450 million Africans are expected to reach working age over the next two decades can hope to find decent work (Fox \& Gandhi, 2021, Parsitau, 2021, Carranza et al, 2020, Mesfin, 2020, Johnson \& Ubong, 2020).
This study therefore examined Manufacturing Sector Development as a panacea to Youth Unemployment using empirical data from Africa. The rest of the study is structured in four sections: Section 2 explained the theoretical framework and review relevant literature for the study. Section 3 describes the data sources and methodology used in the study, section 4 presents and discusses the main findings and section 5 concludes and suggest some policy recommendations.

\section{THEORETICAL FRAMEWORK AND LITERATURE REVIEW}

The theoretical Framework adopted as the basic framework for the analysis of manufacturing sector development and youth unemployment in this study is the structural model. The model according to Adejugbe, (1995) is a powerful tool for evaluating the contemporary economic problem of the developing countries. Economic phenomena such as dualism in production, worsening income distribution, unemployment, market failure as well as balance of payment disequilibria are noticeable hypothesis stated under the structuralist model (Meir, 1984). More so, pertinent in the review of the connection between industrial development and youth unemployment are based on the structural change theories of Lewis (1954) and Chenery (1979). The model describes the tool by which economies which are underdeveloped can transform their domestic structures from a heavy reliance on traditional subsistence agriculture to a more urbanized, modern and more industrially diverse manufacturing and service economy.

In describing how this transformation process takes place, the tools of neoclassical price and resource allocation theory and modern econometrics was employed. The framework entails market oriented of the modern sector which made use of capital, equipment and technology and on the other hand, the subsistence sector engages in production for family consumption and depend on non-purchased inputs which involve family labour and land for production. The subsistence sector has the attribute which entails absence of savings and capital formation which can result in an unlimited supply of labour with the marginal productivity in the agricultural sector summing up to zero. The structural model furthermore, showed that surplus labour can be transferred to the modern sector with the assertion that it will guarantee cumulative growth of incomes, employment and rapid structural transformation of the developing economies (Ukonmi, Agha \& Ekpenyong, 2013).

According to Lewis (1954), which underscore the roles of a fixed wage rate and of profits and savings in generating rapid economic expansion of the industrial sector. Lewis supports the claim that saving and investment in the industrial sector stands as the path to economic development in which the occurrence of savings and investment exist because capitalists earn profit. In other words, any alteration to the distribution of income in favour of the capitalist leads to increase in savings 
and investment. The increase in the income of capitalist is expected to result in inequality in the distribution of income which in turn does not ensure high savings. Without a prosperous capitalist class, income distribution might be highly unequal due to high agricultural rent. Therefore, according to Lewis, most of the income might primarily be going to a traditional landlord class that does small saving where the essential to growth is that income must change in favour of the class that saves. A study by Rains and Fel (1961) modified Lewis model placing emphasis on development priority in the industrial sector which can trigger labour migration from subsistence sector into wage employment. Therefore in a short time surplus labour would cease to exist in the subsistence sector. However, the argument was in the favour of modern sector as it is assumed that the process of reinvestment of the capitalist surplus will serve as a source of creating new capital. This process of creating new capital will take technological development of industries as priority in order to employ more labour.

In accordance with empirical structural change analysts which emphasize the fact that developing countries are part of a highly integrated international system which can either promote or hinder their development. It was stressed that for a nation to experience significant economic development and enlargement in living standards, the manufacturing sector need to undergo a much more rapid growth than the other sectors and tremendously increase its share of national output. Based on the assertion of the structuralist, rapid growth of the manufacturing sector implies industrialization and the effectiveness of industrialization must however be based on adequate employment of labor and capacity fully utilized.

Few research work has shown the nexus between manufacturing sector development and youth unemployment. Studies from across Africa have revealed that industrialization through manufacturing sector growth and development is an important driver of employment growth in developing countries (see Athukorala \& Sen, 2014; Raufu \& Alan, 2016; Hinh \& George, 2012; Ebandalla, 2016; Okorie and Anowor, 2017). A robust manufacturing sector is the engine of growth in both developed and developing economies as revealed in the study by Raufu and Alan (2016). The study explored the explanatory powers of Foreign Direct Investment, Interest rate, inflation, labour cost, and government incentives relative to manufacturing sector growth in sub-Saharan African Countries from 2008-2010. Findings from the study revealed a positive significant relationship of the manufacturing sector to foreign direct investment and labour cost. The debate on the role of industrialization in employment generation and poverty reduction in developing countries was revealed in a study by Athukorala \& Sen (2014) through an interpretative survey of the literature supplemented with relevant stylized fact. The study rejected the emphasis on forced import substitution through protection and state intervention and emphasized growth prospects and poverty alleviation through employment generation. Based on the findings from the study, this can only be achieved by industrialization through greater integration into the international economy.

In a book published by Hinh \& George (2012) which revealed both the formal and informal characteristics of manufacturing firms in Africa by comparing these firms with firms in other regions. Drawing on two data sources, the authors found out that there is a very low share of manufacturing in GDP in Africa and in Africa export thereby contributing to the level of unemployment and poverty in the continent. In a report by Signe (2018) which discussed the evolution and prospects of manufacturing and industrialization in Africa with emphasis on the trends, perspectives and strategies for effective investment by 2030 . The findings from the report provides policymakers with some options likely to attract private investors, accelerate manufacturing and industrial development and to contribute to growth and poverty alleviation thereby facilitating the fulfilment of the sustainable development goals and the African Union's Agenda 2063.

The determinants of the manufacturing sector growth was examined by Manoj (2018) in a study from Ethiopia using aggregate data compiled by the Central Statistical Agency (CSA). With the use of secondary data and descriptive analysis, findings revealed that manufacturing sector growth have a positive relationship with permanent employment in the country. A similar study by Moyo (2017) reviews and analysed the manufacturing experience of three African countries namely Mauritius, South Africa and Botswana. With the use of secondary information findings showed the role played by a strong development state, formulation and implementation of long-term industrial strategic frameworks, creation of effective institutions, reintroduction of industrial policies and incentives and foreign direct investment.

The necessity for structural transformation in North Africa came up as a result of the need of the sub region for high and sustained growth in order to make significant contribution towards generating increased productive and quality jobs and livelihood for its teeming population especially youth. This prompted Anyanwu (2017) to empirically assess the key drivers of manufacturing value added in the sub-region using a time series cross-sectional data set of the countries for the period 1990-2014. Two estimation techniques, the pooled panel OLS regression with year fixed effects and the IV-2SLS estimation procedure were used. Findings revealed a negative effect of age dependency ratio (Youth) to MVA and a positive effect of FDI, domestic credit to private sector, trade openness to MVA.

Another study by Atsede and Arvind (2017) analysed the role of manufacturing industries in stimulating economic advancement and development in Ethiopia over the past three decades. The study further examined the role of manufacturing industries in promoting economic growth and development in Ethiopia. The study employs secondary data collected from different sources: Central Statistical Agency (CSA), National Bank of Ethiopia (NBE) and Ministry of Finance and Economic Development (MoFED). The study 
period covered was between 1986 and 2015.The study applied both descriptive and inferential statistics. The analysis indicates that manufacturing sector distribution is concentrated only to the major urban area and some region. In the study period, the number of manufacturing establishments increased from 408 to 3,139 which have showed additional 2,731 new manufacturing industries during the last three decades. Furthermore, the employment opportunity by the sector increased from 85,623 to 315,263 during the study period. The model estimation indicated a unit percent change in the growth rate of manufacturing industries output increase economic growth by 12 percent in the country. In addition to this, the manufacturing sector positively affects employment in the manufacturing sector. The absence of selective government policy and poor competitive advantage of the sector in the international market have been strongly affecting the impact of the sector on national economy.

The above review of the extant literature shows that there is dearth of empirical literature on the subject matter in Africa. Most studies in the literature are country-specific studies. In addition, majority of the country-specific studies concentrated on the impacts of manufacturing industry on economic growth, thereby neglecting the role of structural transformation in the aspect of youth unemployment. Lastly, few studies that examine the effect of manufacturing sector on employment do not use bring out the long run effect of manufacturing sector in the creation of decent jobs. Therefore, this study contributed to the extant literature by examining the long run effects of manufacturing sector development on youth unemployment in Africa.

\section{III.METHODOLOGY}

\section{Sources of Data and Measurement of Variables}

The present study has collected annual data covering the period of 2000 - 2018 for 33 African countries from the World Development Indicators of the World Bank (2018). The choice of the time frame was purposively done based on the time of inception of Millennium Development goals and the ongoing Sustainable Development Goals. Based on the availability of data, the study takes into consideration 33 African countries namely: Angola, Benin, Botswana, Cote d' ivore, Cameroon, Congo Democratic Republic, Cape Verde, Algeria, Egypt, Ethiopia, Ghana, Kenya, Liberia, Lesotho, Morocco, Madagascar, Mauritius, Malawi, Namibia, Niger, Nigeria, Rwanda, Senegal, Seychelles, Chad, Togo, Tunisia, Uganda, South Africa, Zambia, Zimbabwe, Tanzania and Mozambique. The main variable that has been used in the literature to proxy manufacturing sector is value added of manufacturing (Alexiou \& Tsaliki, 2010; Gui-Diby \& Renard, 2015; Marconi et al., 2016; McCausland \& Theodossiou, 2012; Szirmai \& Verspagen, 2015) with the determinants of the manufacturing sector used as control variables such as foreign direct investment, domestic credit provided by the financial sector, and gross capital formation as identified in the literature. Youth unemployment is measured using the share of the labor force ages 15-24 without work but available for and seeking employment.

\section{Model Specification}

The first empirical work of this study is to check for the stationary properties of the variables in which the study applied Pesaran CADF test (Pesaran 2007). The presence of cross sectional among the variables can be solved by augmenting the standard Dickey Fuller regression with cross sectional averages of lagged levels and first differences of the individual series (Pesaran, 2007). The Pesaran CADF equation is as follows;

$$
\Delta y_{i, t}=\beta_{i}+\alpha_{i} y_{i, t-1}+\sum_{j=1}^{m} \gamma_{i} \Delta \bar{y}_{t-1}+\Delta y_{i, t-j}+\lambda_{i t}+\varepsilon_{i, t}
$$

where $\beta_{i}$ and $\lambda_{i t}$ are unit root specific fixed and time effects respectively. The null hypothesis states the presence of unit root while alternate hypothesis suggests stationarity in the panel. The IPS test is like testing unit root for all cross section units.

In estimating the long-run relationship among the variables, the study applied Panel Autoregressive Distributed Lag Model which proposes an intermediate coefficient that allows the equality of coefficient between countries in the long term and difference in coefficients between groups in the short term (Pesaran et al., 2001). The importance of Pooled Mean Group/ARDL as a technique is that it allows the short term dynamic coefficients to differ from country to country and constrains the long term coefficients to be the same. More so, the model shows the adjustment dynamism between short and long term (Kannadhasan, Aramvalarthan, Balasubramanian \& Aishwaya, 2017). Therefore, the long term relationship between Youth unemployment and the determinants of the manufacturing sector development is expected to be the same for all countries while short term coefficients are expected to be country specific. This method also assumes that error terms are not serially correlated and independent variables follow independently identically distributed. In the choice of optimal lag length, the lowest value of Akaike Information Criteria (AIC) (Akaike, 1973) is used. For this study, the lag length is 1 for all the variables. According to Pesaran et al. (1999), an ARDL dynamic heterogeneous panel regression can be written by using $\operatorname{ARDL}(p, q)$ approach where ' $p$ ' is the lags of dependent variable and ' $q$ 'is the lags of independent variables. The equation was adapted from the work of Kannadhsan et al., (2017) and can be re-written as;

$$
\begin{gathered}
\text { YUEMP } P_{i t}=\alpha_{i}+\sum_{j=1}^{P_{i}} \beta_{i j} Y U E M P_{i, t-j}+\sum_{j=0}^{q_{i}} \delta_{i j} M V A_{i, t-j}+\sum_{j=0}^{k_{i}} \theta_{i j} F D I_{i, t-j} \\
+\sum_{j=0}^{I_{i}} \gamma_{i j} G C F_{i, t-j}+\sum_{j=0}^{m_{i}} \lambda_{i j} D C P_{i, t-j}+\varepsilon_{i t}
\end{gathered}
$$

2

Where: $i=1,2,3, \ldots \ldots \ldots N$ number of cross section

$$
\text { (Here } i=N=33 \text { ) }
$$




$$
t=1,2,3 \ldots \ldots \ldots . . \text { total time period }(T=19)
$$

If the variables in Equation 2 are I (1) and co-integrated than the error term should follow I (0) order in all cross-sections to have long-run equilibrium relationship between the variables. The principal feature of co-integrated variables is that their time paths are influenced by the extent of any deviation from long run equilibrium. This explains that an error-correction model in which the short run dynamics of the variables in the system can be influenced by the deviation from equilibrium. Panel ARDL can be applied even if the variables follow different order of integration i.e. I (0) and I (I) or a mixture of both. As suggested by Pesaran et al., (1999), Equation 2 was re-parameterized into the following error correction equation;

$$
\begin{array}{r}
\triangle \text { UUEMP }_{i t}=\alpha_{i}+\beta_{i}{ }^{*} Y U E M P_{i, t-1}+\delta_{i}{ }^{*} M V A_{i t}+\theta_{i}{ }^{*} F D I_{i t}+ \\
\gamma_{i}{ }^{*} G C F_{i t}+\lambda_{i}{ }^{*} D C P_{i t}+\sum_{j=1}^{P_{i-1}} \beta_{i j}{ }^{* *} Y U E M P_{i, t-j} \\
\sum_{j=0}^{q_{i}} \delta_{i j}{ }^{* *} M V A_{i, t-j}+\sum_{j=0}^{k_{i}} \theta_{i j}{ }^{* *} F D I_{i, t-j}+ \\
\sum_{j=0}^{I_{i}} \gamma_{i j}{ }^{* *} G C F_{i, t-j}+\sum_{j=0}^{m_{i}} \lambda_{i j}{ }^{* *} D C P_{i, t-j}+\varepsilon_{i t}
\end{array}
$$

3

Equation 3 are the main equation of interest and is estimated by pooled mean group estimator where $\delta_{i}{ }^{*} \theta_{i}{ }^{*}$, $\gamma_{i}{ }^{*}, \lambda_{i}{ }^{*}$ and $\beta_{i j}{ }^{* *} \delta_{i j}{ }^{* *} \theta_{i j}{ }^{* *} \gamma_{i j}{ }^{* *} \lambda_{i j}{ }^{* *}$ are the long run and short run coefficients respectively. Also $\beta_{i}{ }^{*}=-\left(1-\sum_{j=1}^{P_{i}} \beta_{i j}\right)$, $\delta_{i}{ }^{*}=\sum_{j=0}^{q_{i}} \delta_{i j}, \quad \theta_{i}{ }^{*}=\sum_{j=0}^{k_{i}} \theta_{i j}, \quad \gamma_{i}{ }^{*}=\sum_{j=0}^{I_{i}} \gamma_{i j}, \lambda_{i}{ }^{*}=$ $j=0$ miגij

\section{RESULTS AND DISCUSSION}

In order to investigate the effect of manufacturing sector development on youth unemployment in Africa, we begin our analysis with descriptive analysis. We first examine the descriptive statistics and the correlation matrix of variables used. The descriptive statistics of the data series provides information about sample statistics such as mean, median, minimum value, maximum value and distribution of the sample measured by the skewness, kurtosis and the JarqueBera statistic. The descriptive statistics is provided in Table 1. The data display a high level of consistency as their mean and median fall within the range of minimum and maximum values of the series. The mean value of youth unemployment and manufacturing valued added showed $2.5 \%$ and $2.2 \%$ respectively which implies that youth unemployment is still rampant in the continent with manufacturing sector output still at the lowest during the study period. Also the foreign direct investment in the continent is still at the lowest. The standard deviations are generally very low, showing that deviations of the actual data from their mean values are small. However, the standard deviation of youth unemployment showed the highest at $1.2 \%$, indicating that it is a major variable that the continent needs to concentrate on when compared with other variables for the achievement of other sustainable development goals such as poverty, decent jobs, inclusive growth etc. Descriptive statistics also shows that all of the variables are negatively skewed and platykurtic (skewed) relative to the normal. Finally the probability that the Jarque-

\begin{tabular}{|c|c|c|c|c|c|}
\hline & $\begin{array}{c}\text { LYUEM } \\
\mathrm{P}\end{array}$ & LMVA & LFDI & LGCF & LDCP \\
\hline Mean & 2.454433 & 2.227399 & 0.946808 & 3.126699 & 3.122328 \\
\hline Median & 2.719794 & 2.309512 & 0.985707 & 3.157856 & 3.087311 \\
\hline Maximum & 4.120232 & 3.924658 & 4.637999 & 4.096944 & 4.971761 \\
\hline Minimum & 0.729189 & $\begin{array}{c}- \\
1.692034 \\
\end{array}$ & $\begin{array}{c}- \\
3.198256 \\
\end{array}$ & 0.422110 & $\begin{array}{c}- \\
1.561454 \\
\end{array}$ \\
\hline Std. Dev. & 1.164996 & 0.727410 & 1.107741 & 0.416192 & 1.051836 \\
\hline Skewness & $\begin{array}{c}- \\
0.660152\end{array}$ & $\begin{array}{c}- \\
1.516656\end{array}$ & $\begin{array}{c}- \\
0.311516\end{array}$ & $\begin{array}{c}- \\
1.276877 \\
\end{array}$ & $\begin{array}{c}- \\
0.828031 \\
\end{array}$ \\
\hline Kurtosis & 2.708764 & 7.669357 & 4.281468 & 8.633839 & 4.444738 \\
\hline $\begin{array}{c}\text { Jarque- } \\
\text { Bera } \\
\end{array}$ & 47.75710 & 809.9764 & 53.04234 & 999.5898 & 126.1787 \\
\hline Probability & $\begin{array}{c}0.000000 \\
* * *\end{array}$ & $\begin{array}{c}0.000000 \\
* * *\end{array}$ & $\begin{array}{c}0.000000 \\
* * *\end{array}$ & $\begin{array}{c}0.000000 \\
* * *\end{array}$ & $\begin{array}{c}0.000000 \\
* * *\end{array}$ \\
\hline Sum & 1538.929 & 1396.579 & 593.6483 & 1960.440 & 1957.699 \\
\hline $\begin{array}{c}\text { Sum Sq. } \\
\text { Dev. }\end{array}$ & 849.6163 & 331.2322 & 768.1582 & 108.4332 & 692.5811 \\
\hline $\begin{array}{c}\text { Observatio } \\
\text { ns }\end{array}$ & 627 & 627 & 627 & 627 & 627 \\
\hline
\end{tabular}
Bera statistics exceeds (in absolute terms) the observed value is generally low for all the series. This therefore implies a rejection of normal distribution at $1 \%$.

Table 1: Descriptive Statistics

Where $* * *, * *, *$ represent $1 \%, 5 \%$, and $10 \%$ significant level respectively Source: Author's Computation, 2021

The next step is to examine the possible degree of association among the variables. The study employs correlation matrix to achieve this objective and its result is presented in Table 2 . Results show the correlation coefficients and the directions of the relationship among the variables. From the results, manufacturing value added as a proxy for manufacturing sector development, gross capital formation and domestic credit to private sector show a positive association with youth unemployment while foreign direct investment and poverty showed a negative relationship with youth unemployment. It also reveals that these variables do not have a strong relationship with youth unemployment. Generally, the correlation matrix has shown interesting results on the relationship between dependent and independent variables. In addition, none of these variables show a strong relationship as all the correlation coefficients are less than 0.5. Nevertheless, caution should be exercised in interpreting results from correlation, because simple bivarite correlation in a conventional correlation matrix in Table 2 only portrays the extent of the linear relationship between pairs of relationship used in this study. Also correlation between this study variables does not mean causation. Thus negative or positive correlation coefficients reported in Table 2 only depict the 
extent of the linear relationship between pairs of variables used.

Table 2: Correlation Matrix

\begin{tabular}{|c|c|c|c|c|c|}
\hline $\begin{array}{l}\text { Correlation/Probabi } \\
\text { lity }\end{array}$ & $\begin{array}{l}\text { LYUEM } \\
\text { P }\end{array}$ & LMVA & LFDI & $\begin{array}{l}\mathrm{LG} \\
\mathrm{CF}\end{array}$ & $\begin{array}{l}\mathrm{LD} \\
\mathrm{CP}\end{array}$ \\
\hline LYUEMP & 1.00 & & & & \\
\hline LMVA & $\begin{array}{c}0.14 \\
0.00^{* * *}\end{array}$ & 1.00 & & & \\
\hline LFDI & $\begin{array}{l}-0.05 \\
0.23\end{array}$ & $\begin{array}{c}-0.18 \\
0.00 * * \\
*\end{array}$ & 1.00 & & \\
\hline LGCF & $\begin{array}{c}0.09 \\
0.03 * *\end{array}$ & $\begin{array}{c}-0.06 \\
0.13\end{array}$ & $\begin{array}{c}0.31 \\
0.00^{* *} \\
*\end{array}$ & 1.00 & \\
\hline LDCP & $\begin{array}{c}0.27 \\
0.00 * * *\end{array}$ & $\begin{array}{c}0.14 \\
0.00^{* *} * \\
*\end{array}$ & $\begin{array}{c}-0.00 \\
0.92\end{array}$ & $\begin{array}{l}0.01 \\
0.76\end{array}$ & 1.00 \\
\hline
\end{tabular}

Where $* * *, * *, *$ represent $1 \%, 5 \%$, and $10 \%$ significant level respectively Source: Authors' Computation, 2021

The result of PCADF are given in Table 3 where YUEMP and FDI are stationary at their level while MVA, GCF and DCP are stationary at their first difference. If all the variables are stationary at their level, fixed effect or random effect model is used. On the other hand, if all the variables are stationary at their first difference, Panel Fully Modified OLS or Panel Dynamic OLS is estimated. In addition to theoretical proposition, if some variables are stationary at their level and some variables are stationary at their first differences, Autoregressive Distributed Lag Models are estimated (Pesaran, Shin and Smith, 1999). The PCADF result i.e. I (0) and I (1) suggests that standard OLS cannot be used. Since the constant is changing with time, OLS estimates are likely to give high t-values and $\mathrm{R}^{2}$ value leading to a spurious regression. To avoid such problem, a model that incorporate $\mathrm{I}(0)$ and $\mathrm{I}(1)$ in the same equation is required. Therefore, this study employed the use of Pooled Mean Group Estimation (PMG/ARDL) introduced by Pesaran (2001).

Table 3: Pesaran's Cross Sectional Augmented Dickey Fuller (CADF) Test results

\begin{tabular}{|c|c|c|c|c|}
\hline & \multicolumn{2}{|c|}{ Intercept } & \multicolumn{2}{c|}{ Intercept and Trend } \\
\hline Variable & $\mathrm{t}-$ bar & $\mathrm{p}$-value & $\mathrm{t}$-bar & $\mathrm{p}$-value \\
\hline YUEMP & -6.47 & $0.00 * * *$ & -5.57 & $0.00 * * *$ \\
\hline$\Delta$ YUEMP & -17.56 & $0.00 * * *$ & -13.05 & $0.00 * * *$ \\
\hline MVA & -2.34 & $0.01 * *$ & -1.42 & $0.08 *$ \\
\hline$\Delta$ MVA & -15.50 & $0.00 * * *$ & -9.96 & $0.00 * * *$ \\
\hline FDI & -8.94 & $0.00 * * *$ & -7.52 & $0.00 * * *$ \\
\hline$\Delta$ FDI & -22.30 & $0.00 * * *$ & -16.23 & $0.00 * * *$ \\
\hline GCF & -3.40 & $0.00 * * *$ & -3.31 & $0.00 * *$ \\
\hline$\Delta$ GCF & -14.35 & $0.00 * * *$ & -10.92 & $0.00 * * *$ \\
\hline DCP & -2.24 & $0.01 * *$ & -4.37 & $0.00 * * *$ \\
\hline$\Delta$ DCP & -13.67 & $0.00 * * *$ & -10.77 & $0.00 * * *$ \\
\hline
\end{tabular}

Where $* * *, * *, *$ represent $1 \%, 5 \%$, and $10 \%$ significant level respectively Source: Author's Computation, 2021

\section{Result of Panel ARDL}

The existence of cointegration from the result in Table 3 confirms the presence of error correction mechanism among the variables. The lag length of all the variables are one (ARDL 1, 1,1,1,1). The result from Table 4 revealed that LMVA, LGCF, LFDI and LDCP are positively related to LYUEMP. This implies that on the long run, the growth of the manufacturing sector, the capital formation level, foreign direct investment and domestic credit to private sector stands as the main solution to Youth Unemployment in Africa. The short run equation indicates that error correction mechanism is significant as this can take care of any instability or shock in an economy by restoring it back to a stable level. More so, in the short run, the result revealed that a change in MVA and DCP is positively related to Youth Unemployment which implies that African countries need to work towards the development of the manufacturing sector especially through the production of tangible goods that can make the free trade to survive in the continent. Also, countries in Africa should make domestic credit available to private sector and entrepreneurs, On the other hand, a change in FDI and GCF revealed a negative relationship with youth unemployment at the short run. This implies that countries in Africa has not been attracting foreign direct investment into their economy thus reflecting on the capital formation of the countries which invariably contributed to the menace of youth unemployment. This results conform to the work of Eseyin, Oloni, Ogunjobi \& Abiodun (2021), Pasara \& Garidziral (2020), Atsede \& Arvind (2017), Raufu \& Alan (2016), Anyanwu (2017).

Table 4: Result of Panel ARDL

\begin{tabular}{|c|c|c|c|c|}
\hline Variable & $\begin{array}{c}\text { Coefficien } \\
t\end{array}$ & Std. Error & t-Statistic & Prob.* \\
\hline & \multicolumn{2}{|c|}{ Long Run Equation } & & \\
\hline $\begin{array}{c}\text { LYUEMP(- } \\
1)\end{array}$ & -0.052155 & 0.096509 & $\begin{array}{c}- \\
0.540423 \\
\end{array}$ & 0.5892 \\
\hline LMVA & 0.043652 & 0.083688 & 0.521609 & 0.6023 \\
\hline LGCF & 0.076526 & 0.030927 & 2.474410 & $0.0138 * *$ \\
\hline LFDI & 0.025806 & 0.050172 & 0.514353 & 0.6073 \\
\hline \multirow[t]{2}{*}{ LDCP } & 0.309912 & 0.000000 & NA & $\begin{array}{c}0.0000 * * \\
*\end{array}$ \\
\hline & \multicolumn{2}{|c|}{ Short Run Equation } & & \\
\hline $\begin{array}{c}\text { COINTEQ0 } \\
1\end{array}$ & -0.313488 & 0.044432 & $\begin{array}{c}- \\
7.055366\end{array}$ & $\begin{array}{c}0.0000 * * \\
*\end{array}$ \\
\hline $\begin{array}{c}\text { D(LYUEM } \\
\mathrm{P}(-1)) \\
\end{array}$ & 0.045942 & 0.041080 & 1.118344 & 0.2642 \\
\hline D(LMVA) & 0.198675 & 0.260191 & 0.763573 & 0.4456 \\
\hline $\mathrm{D}(\mathrm{LGCF})$ & -0.002723 & 0.115559 & $\begin{array}{c}- \\
0.023561 \\
\end{array}$ & 0.9812 \\
\hline $\mathrm{D}(\mathrm{LFDI})$ & -0.004321 & 0.021948 & $\begin{array}{c}- \\
0.196895 \\
\end{array}$ & 0.8440 \\
\hline $\mathrm{D}(\mathrm{LDCP})$ & 0.241512 & 0.171124 & 1.411326 & 0.1590 \\
\hline $\mathrm{C}$ & 0.736177 & 0.138799 & 5.303907 & $\begin{array}{c}0.0000^{* * *} \\
*\end{array}$ \\
\hline
\end{tabular}

Where $* * *, * *, *$ represent $1 \%, 5 \%$, and $10 \%$ significant level respectively Source: Author's Computation, 2021 


\section{CONCLUSION}

The objective of this study is to examine the long run effect of manufacturing sector development on youth unemployment in Africa. This was carried out through the use of the technique of Panel Autoregressive Distributed lag which deals with the stationary series problem of different orders and allows us to study potential long term effects of structural economic policies. A panel data of thirty-three (33) countries was selected for the study. Our selection is based on the availability of data. The correlation results show that our model is free from serial correlation problem and the PCADF results revealed that our variables are stable. Results showed that manufacturing value added, foreign direct investment, gross capital formation and domestic credit to private sector have positive long run relationship with youth unemployment which implies that for most African countries to curb the menace of youth unemployment ravaging the continent now and in future years, the focal point of policy making must be directed towards the development of the manufacturing sector, creating a conducive economic environment so as to attract foreign direct investment, establish institutions to enhance capital formation and make domestic credit available to new and existing entrepreneurs and industrialist. The study concludes that in the bid to revamp the manufacturing sector, structural transformation through reviving the upcoming, new and old manufacturing industries need to be put in place so as to pave way for new technology to come into the production process thereby enhancing creation of decent jobs and wage which can contribute to eradication of poverty, enhance sustainable development and inclusive growth.

\section{POLICY RECOMMENDATIONS}

Based on the findings of the study, the following policy recommendations were made.

The existence of a positive and significant effect of the Manufacturing value added on youth unemployment in the short run and long run implies that manufacturing sector development is a major and effective tool that can be used to curb the menace of youth unemployment plaguing the continent. In connection with a study by Johnson and Ubong (2020) which identified the manufacturing sector as a catalyst for job creation, a pathway to capital, technological innovation and learning. The study thus recommended that policy makers in each nations of Africa should look towards the direction of enhancing manufacturing value added as a means of creation of employment and decent jobs which will enhance economic development and social progress.

Domestic credit to private sector exert a positive and significant effect on youth unemployment in Africa both in the long run and in the short run. By implication, as shown from literature that domestic credit increases productive capacity of business thereby enhancing greater potential to grow through sales, revenues, expand investment and operations. It is therefore recommended that African Countries policy makers should strive towards making domestic credit available to potential and active entrepreneurs in the bid to enhance expansion of the manufacturing sector which in return can create jobs and employment opportunities.

Gross capital formation and Foreign Direct Investment exert a negative and significant on youth unemployment in Africa in the short run and a positive significant effect on the long run. This implies that the impact of the two investment variables, Gross Capital Formation and Foreign Direct Investment may not contribute to the reduction of unemployment of youth in the region at the initial stage of implementing development and expansion of the manufacturing sector through capital formation and foreign investors. But on the long run, the effect will reflect as more youth will be employed into productive and decent jobs as the manufacturing sector expands and develops as a result of continuous gross capital formation and foreign investors input. The study therefore recommends that policy makers in most African countries should put in effort of working towards gross capital formation and attracting foreign direct investment for manufacturing sector expansion.

The study made suggestion for further studies in the area of identifying the expansion and growth factors that can trigger manufacturing sector development towards creation of decent jobs and employment opportunities in the bid to eradicate youth unemployment in Africa. This should be done based on the idiosyncrasies of each country in the region.

\section{REFERENCES}

[1] Abdychev, A., Alonso, C., Alper, M. E., Desruelle, M. D., Kothari, S., Liu, Y., Perinet, M., Rehman, S., \& Schimmelpfennig, M. A. (2018). The Future of Work in Sub-Saharan Africa. International Monetary Fund.

[2] Adegboye, A. C., Egharevba M.I., \& Edafe J. (2019). Economic regulation and employment intensity of output growth in subSaharan Africa. In A. Elhiraika, G. Ibrahim G, \& W. Davis (Eds.), Governance for structural transformation in Africa: 101-143). Palgrave Macmillan.

[3] Adejugbe, M. O. A. (1995). Macroeconomic policies and the industrial sector. In: Akin Iwayemi (ed.) Macroeconomic policy issues in an open development economy: A case study of Nigeria. Ibadan: University of Ibadan Press.

[4] African Development Bank (AfDB). (2016a). Bank Group Strategy for Jobs for Youth in Africa, 2016-2025.

[5] African Development Bank AfDB. (2016b). Jobs for youth in Africa: Catalyzing youth opportunity across Africa. African Development Bank Group.

[6] Anyanwu, J. C. (2013). Characteristics and Macroeconomic Determinants of Youth Employment in Africa, African Development Review, 25(2):107-29.

[7] Anyanwu, J. C. (2017). Manufacturing Value Added Development in North Africa: Analysis of key Drivers Macroeconomic Policy, Forecasting and Research Department, African Development Bank; Abidjan, Cote d' Ivoire.

[8] Akaike, H. (1973). Information theory and an extension of the maximum likelihood principle, in: B. N. Petrov and F. Csaki, eds., 2nd International Symposium on Information Theory (Akademia Kiado, Budapest): 267-281.

[9] Athukorala, P. and Sen K., (2014). 'The Determinants of Employment Intensity of Manufacturing in Developing Countries', Institute for Development Policy and Management, University of Mancester (Mimeo). 
[10] Atsede, A. \& Arvind, K. B., (2017). Assessing the role of Manufacturing Industries in Stimulating Economic Advancement and Development in Ethiopia; International Journal of Science Technology and Management; 6(5): 304-313

[11] Baah-Boateng, W., (2016). The youth unemployment challenge in Africa: What are the drivers? The Economic and Labour Relations Review, 27(4): 413-431.

[12] Beegle, K., \& Christiaensen, L. (2019). Accelerating poverty reduction in Africa. World Bank Publications.

[13] Bhorat, H., Christopher, R., and François S., (2016). "Africa's Manufacturing Malaise." United Nations Development Programme Regional Bureau for Africa Working Paper Series, 1(3), New York, NY: UNDP.

[14] Bhorat, H., Ravi K., Christopher R., and François S., (2017). SubSaharan Africa's manufacturing Sector: Building Complexity. Working Paper Series No.256. Abidjan, Côte d'Ivoire: African Development Bank Group.

[15] Carranza, E., Garlick, R., Orkin, K., \& Rankin, N. (2020). Job search and hiring with two-sided limited information about work seekers' skills. Policy Research Working Paper, No. 9345. World Bank, Washington, DC.

[16] Diao, X. Ellis, M. McMillian, M. \& Rodrik, D. (2021). Africa's Manufacturing Puzzle: Evidence From Tanzanian and Ethiopian Firms. NBER Working Paper, w28344.

[17] Dinh, Hinh T. Clarke, George R.G. (2012). Performance of Manufacturing Firms in Africa: An Empirical Analysis. Directions in Development; Private Sector Development; Washington, DC: World Bank. (c) World Bank.

[18] Eseyin, O. Oloni, E. Ogunjobi, O. \& Abiodun, F. (2021). Governance and Youth Unemployment in Nigeria, International Journal of Financial Research, 12(1): 220-231.

[19] Filmer, D. \& Fox, L. (2014). Youth Employment in Sub-Saharan Africa. The World Bank http://elibrary.worldbank.org/doi/book/10.1596/978-1-4648-01075

[20] Fox, L. \& Thomas, A., (2016). Africa's Got Work to Do: A Diagnostic of Youth Employment Challenges in sub-Saharan Africa, Journal of African Economies, 25(1):16-36.

[21] Fox, L \& Ghandi, D. (2021). Youth Employment in sub-Saharan: Progress and Prospect: Africa Growth Initiative at Brookings: AGI Working Paper No 28.

[22] Hinh, T. D. \& George R. G. C. (2012) Performance of the Manufacturing Firms in Africa: An Empirical Analysis, World Bank Publications, the World Bank, 2: 959

[23] Im, K.L. Pesaran, M.H. \& Shin, Y. (2003). Testing for unit roots in heterogeneous panels. Journal of Econometrics, 115(1): 53-74.

[24] International Labour Organization (2016). Youth unemployment challenge worsening in Africa, Available at http://www.ilo.org/addisababa/mediacentre/pr/WCMS_514566/lang--en/index.htm

[25] KPMG. (2013). Manufacturing in Africa: Sector Report

[26] Johnson, A. A. \& Ubong, E. E. (2020). Industrialization and youth Unemployment in Nigeria: An Autogressive Distributive Lag (ARDL) Approach: International Journal of Business and Economics Research. 9(5): 334-344.

[27] Jostein, H. L., (2015). Smart Industrial Policy for Africa in the 21 st Century. PowerPoint Slides.

[28] Flynn, J. \& Yeboah, T. (2021). Rural Youth Employment in Africa: An Evidence Review: Evidence Synthesis Paper Series.

[29] Kannadhasan M., Aramvalarthan S., Balasubramanian, P., \& Aishwaya, G. (2017) Determinants of Dividend Policy of Indian Manufacturing Companies: Panel Autoregressive Distributed Lag Analyssis: Academy of Accounting and Financial Studies Journal, 21(2)

[30] Lewis, A. W. (1954). Economic development with unlimited supplies of labour. The Manchester School.

[31] Manoj, K. M. (2018) Determinants of Manufacturing Sector Growth in Ethiopia Amity. Journal of Management 6(2): 1-12

[32] Maryla \& Michele (2020). The African Continental Free Trade Area: Economic and Distributional Effects. International Bank for Reconstruction and Development/The World Bank
[33] Mesfin, W. B. (2020). Empirical Analysis of Urban Youth Unemployment in Ethiopia: African Development Review; 33:104116.

[34] Mueller, V. \& Thurlow, J. (2019). Youth and Jobs in Rural Africa: Beyond Stylized Facts. Oxford:Oxford University Press.

[35] Nzewi, H. N \& Ojiagu, N. C (2014). Structural Youth Unemployment and Productivity in sub-Saharan Africa: The Nigerian Manufacturing Sector Experience (2000-2013). European Journal of Business and Management 6(37): 310-314.

[36] Moyo, T., (2016) Promoting industrialization in Mauritius, South Africa and Botswana: Lessons for the future; African Development 41(3):139-163

[37] Okurebia, S. O (2014). Industrialization, Youth Employment and Capacity Utilization in Africa: Some Fundamental Problem: European Journal of Business and Management. 6(27): 16-21

[38] United Nations Conference on Trade and Development (UNCTAD) Policy Brief, No 27, August 2013

[39] United Nations (2015) Youth population trends and sustainable development, Population Facts, Available at: http://www.un.org/esa/socdev/documents/youth/factsheets/YouthPOP.pdf

[40] Page, J., (2012). Youth, jobs, and structural change: confronting Africa's 'employment problem'. Working Paper No. 155. African Development Bank Group.

[41] Page, John. 2018. The Road not Taken: Structural Change in Africa Reconsidered. In Foresight Africa: Top Priorities for the Continent in 2018. Washington DC: Brookings Institution.

[42] Pasara, M. T \& Garidzirai, R (2020). Causality Effects among Gross Capital Formation, Unemployment and Economic Growth in South Africa, Economies, 8(26): 1-12.

[43] Patel, L, Khan, Z \& Englert, T, 2020. How might a national minimum wage affect the employment of youth in South Africa? Development Southern Africa 37(1), 147-161. doi:10.1080/0376835X. 2018.1552556.

[44] Pesaran, M. H., (2005). A simple panel unit root test in presence of cross section dependence. Cambridge University Working Paper.

[45] Pesaran, M. H. Shin Y. \& Smith R. (2001), Bounds testing approaches to the analysis of level relationships. Journal of Applied Econometrics, 16(3), pp 289-326.

[46] Ranis, G. and Fei, J. (1961). A theory of economic development. American Economic Review, 1: 73-84

[47] Rioba, M. (2014).Manufacturing Industry and Economic Growth in Kenya. A Kaldorian Approach (1971-2013), University of Nairobi

[48] Raufu, S. and Alan, H. (2016). The determinants of Manufacturing Sector growth in sub-Saharan African Countries: Research in Business and Economics Journal, Vol 12.

[49] Signe, L. (2018). The potential of manufacturing and industrialization in Africa: Trends, Opportunities and Strategies; Africa Growth Initiative at Brookings.

[50] van Niekerk, A. J. (2020). Towards inclusive growth in Africa. Development Southern Africa 37(3), 519-33. doi:10.1080/0376835X.2020.1736004

[51] Yuan S. I. (2018). The World's Next Great Manufacturing Center. Harvard Business Review, 95:.122-129.

[52] Ukommi, A.S. Agha, E. O. and Ekpenyong, O. A. (2013). Industrial Development and Youth Unemployment: The case of crushed rock quarry industry, Ishiagu, Ebonyi State; Knowledge Review, 28(1)

[53] World Bank (2018) World Development Indicators (accessed 13 March, 2018) 